\title{
Analyzing Student Readiness of e-Learning Implementation in Middle School
}

\author{
Feby Artwodini Muqtadiroh \\ Department of Information Systems \\ Institut Teknologi Sepuluh Nopember \\ Surabaya, Indonesia \\ feby.artwodini@gmail.com, feby@is.its.ac.id \\ Amna Shifia Nisafani \\ Department of Information Systems \\ Institut Teknologi Sepuluh Nopember \\ Surabaya, Indonesia \\ amna@is.its.ac.id
}

\author{
Nadia Silviana \\ Department of Information Systems \\ Institut Teknologi Sepuluh Nopember \\ Surabaya, Indonesia \\ silviana216@gmail.com
}

\begin{abstract}
E-learning is a widely developed mean to support learning process in class. However, student readiness may hinder its application, thus results in its deployment failure. One of the methods to assess student readiness is blended learning model from Tang and Chaw. This model analyzes student readiness by measuring how each student behaves towards six learning aspects namely learning flexibility, online learning, study management, technology, online interaction, and classroom learning. To this point, we investigate the application of blended learning model in SMP Negeri 1 Jember, a middle school in Jember. We collect questionnaire data from the students after delivering one day's intensive training. Afterwards, we analyze the collected data using Generalized Structured Component Analysis (GeSCA) Software to understand the interdependency relationships among prescribed variables. From the analysis, we could individually gauge prescribed variables using e-Learning readines systems by Aydin and Tasci. This measurement is useful to categorize organization readiness level (from low to advance). In the end, we have found that 1) SMP Negeri 1 Jember is ready for e-learning implementation with minor fixes 2 ) There are four significant factors which contribute to student readiness namely Attitude towards learning flexibility, Attitude towards study management, Blended learning adaptability, and Attitude towards classroom learning 3 ) We also prescribe some recomendations to enhance student readiness in the elearning implementation.
\end{abstract}

Keywords-e-Learning Readiness; Blended Learning; Readiness Level; Middle School; GeSCA

\section{INTRODUCTION}

In this global era, technology, specifically information and communication technology (ICT), has been tremendously advancing and adopted in various fields, including in education. One of the application of ICT widely used is in elearning. Hartley, addressed that e-learning is a teachinglearning method using media of internet, intranet or other computer networks to deliver the teaching materials to students [1]. The e-learning implementation will definitely bring a lot of benefits to the users, among other things, the students can participate in the e-learning program wherever as long as there is an access to computers and networks [2].

E-learning comprises two models, i.e.: distant learning and blended learning. The fundamental differences are in the degree of assistance given by the teachers or instructors to the students. In the earlier, the students are supposed to be able to independently learn with minimum assistance from the teachers or instructors. In the later, on the other hand, the students still intensively get assistances from the teachers or instructors [3].

The blended learning is more suitable to implement in education institutions, specifically in high schools. Despite strong intent to involve ICT in the teaching-learning processes, it is inevitable that they still proceed conventionally. The students remain required to attend teaching-learning processes in classes and directly interact with their peers and teacher or instructors.

It is obvious that before implementing e-learning, it requires a number of preparations in order to secure that the elearning processes run successfully. Mungania advises that there are seven main hindrance to implement e-learning that must be well anticipated by educational institutions [4]. However, the specific sorts of factors hindering the e-learning processes faced by the educational institutions much depend of a lot of aspects [5],[6], include a state of condition when each institution may have different interpretations. Accordingly, it is certainly necessary to thoroughly assess the learning readiness before implementing an e-learning. E-learning readiness is a state of both mental and physical of an organization to undergo e-learning experiences [7]. In educational institutions, the views of teachers, instructors and students, particularly the ones of the student, need to be well considered in order to be able to implement e-learning successfully [8].

Researches on students' readiness to implement e-learning have ever been completed by a number of researches. One of 
them was conducted by Tang and Chaw to identify how the attitudes of students towards 6 aspects of learning that can affect the students' readiness to implement blended learning [9], i.e.: learning flexibility, online learning, study management, technology, online interaction, and classroom learning. Consequently, in this proposed model, there are eight variables, namely: attittude towards learning flexibility, attitude towards online learning, attitude towards study management, attitude towards technology, attitude towards online interaction, attitude towards classroom learning, blended learning adaptability, and readiness for blended learning.

Considering some of the offered benefits, some institutions, such as Public Junior High School (SMP Negeri) 1 Jember, start to implement e-learning. Adopting the benefits from the available ICT, the school expects to take the benefits offered by e-learning, for instance: enhanced school quality.

However, the goal of implementing e-learning in SMP Negeri 1 Jember will be unattainable if the readiness of the students as the e-learning users is not first assessed. Therefore, in this research, the readiness of the students in the school in implementing e-learning is first analyzed based on the model advocated [9], and e-LRS evaluation model proposed by Aydin and Tasci in order to be able to categorize the readiness of the students in using e-learning method. Next, recommendations on how to enhance the readiness of the students in implementing e-learning based on factors affecting the degree of readiness will be presented.

\section{METHOD}

This study is divided into three main phases, namely: design phase, implementation phase, results and discussion phase.

\section{A. Design Phase}

This phase is concerning to develop a conceptual model and research hypothesis according to the model of blended learning readiness by Tang and Chaw. From Tang and Chaw model, generated experimental study and questionnaire. Experimental study was conducted during the training by utilizing e-learning website in SMP Negeri 1 Jember.

Tang and Chaw has developed a model to assess how the attitudes of the students towards six learning aspects: Learning Flexibility, Online Learning, Study Management, Technology, Online Interaction, and Classroom Learning[9].

Each of the learning aspects is conceptualized in a construct. With reference to the six aspects, it is proposed that if the students have positive attitudes towards the learning flexibility, online learning, study management, technology, and online interaction, they tend to be able to adapt with the blended learning more easily.

In case the students have positive attitudes towards classroom learning, they tend to be less adapt with the blended learning, as they prefer meeting their peers, teachers and instructors in classrooms physically to meeting them digitally (for instance: web). The model developed by Tang and Chaw is presented in the following Figure 1.
To figure out how those constructs build a higher formative construct, a blended learning adaptibility is configured (in accordance with the blended learninng). To assess the validity of the prediction, a new construct, i.e.: readiness for blended learning, is added. The better the students adapt with the blended learning is, the better readiness to implement blended learning will be.

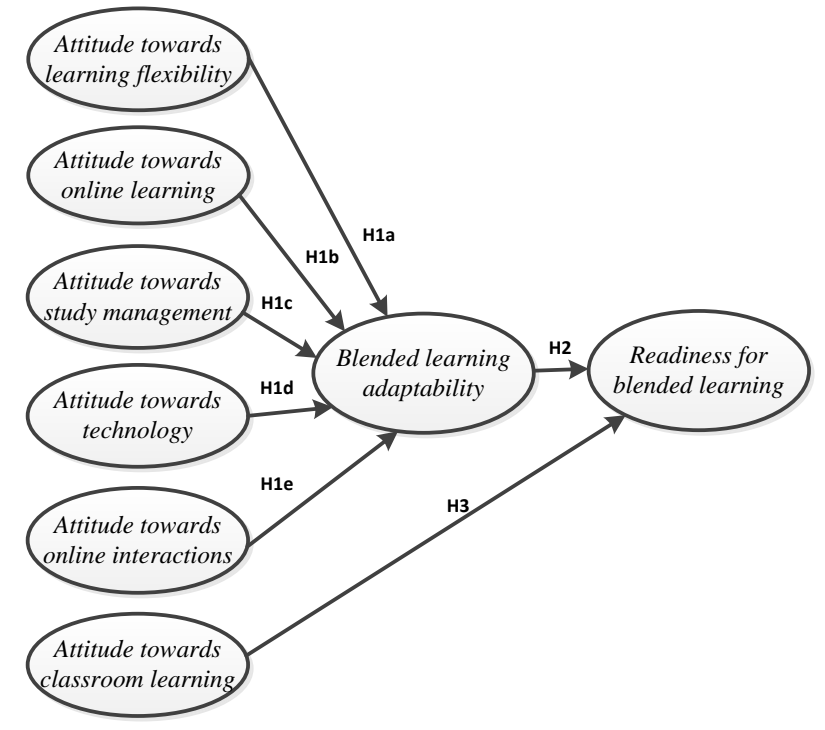

Fig. 1. Tang and Chaw Model

\section{B. Implementation Phase}

The implementation phase is divided into 5 process, the first is to test the questionnaire. The second is to conduct research experiments carried out during the implementation of the training. The third process is distributing questionnaires. The fourth process is to test the validity and reliability by using SPSS thus obtained questionnaire data that is valid and reliable. The fifth process is to perform descriptive and inferential analysis.

\section{Result Analysis and Discussion}

In the implementation phase is divided into two processes, the first is to develop recommendations. The recommendations based on the influence factors according to the hypothesis testing. The second is the process to draw the conclusions from the results of the overall study and suggestions for the development or refinement of the research result.

\section{RESULT AND DISCUSSION}

In this discussion will be explained about the process of data analysis has been obtained from research questionnaires that have been distributed before. This will show the results of the assessment of the level of implementation of e-learning readiness, and the results of testing a student's readiness factor in implementing e-learning. 


\subsection{Research Hypothesis}

In this study, there are seven hypotheses:

1) Students 'attitudes toward learning flexibility has a significant effect on students' ability to adapt to a blended learning (blended learning adaptability)

2) Students 'attitudes toward online learning has a significant effect on students' ability to adapt to a blended learning (blended learning adaptability)

3) Students 'attitudes toward study management has a significant effect on students' ability to adapt to a blended learning (blended learning adaptability)

4) Students 'attitudes toward technology has a significant effect on students' ability to adapt to a blended learning (blended learning adaptability)

5) Students 'attitudes toward online interaction has a significant effect on students' ability to adapt to a blended learning (blended learning adaptability)

6) Students' ability to adapt to a blended learning has a positive effect on student's readiness to implement blended learning (readiness to blended learning)

7) Students 'attitudes toward classroom learning has a negative affect on the student's readiness to implement blended learning (readiness to blended learning)

This study consists of 8 variables and 34 indicators and items of statements referring to the Model of Tang and Chaw. The indicators and items of statements were derived from the seven hypothesis affecting the students' readiness based on the Blended Learning Readiness Model proposed by Tang and Chaw. The following are the lists of indicators and items of statements in this research:

TABLE I. INDICATORS AND ITEMS OF STATEMENTS

\begin{tabular}{|c|c|l|}
\hline Nr & Indicator & \multicolumn{1}{c|}{ Statements } \\
\hline \multicolumn{3}{|c|}{ Attitude towards learning flexibility } \\
\hline 1 & LF1 & $\begin{array}{l}\text { I want to be successful, not only in delivered } \\
\text { learning materials }\end{array}$ \\
\hline 2 & LF2 & $\begin{array}{l}\text { I want to determine myself where I want to learn } \\
\text { (for instance: at home, in class or other places) }\end{array}$ \\
\hline 3 & LF3 & $\begin{array}{l}\text { I want to learn in my own } \\
\text { ways }\end{array}$ \\
\hline 4 & LF4 & I want to determine myself when I will learn \\
\hline 5 & NLF2 & I want someone determine where I will learn \\
\hline \multicolumn{3}{|c|}{ Attitude towards online learning } \\
\hline 1 & OL1 & $\begin{array}{l}\text { I believe that face-to-face learning in classrooms } \\
\text { brings better achievement than e-learning does }\end{array}$ \\
\hline 2 & OL2 & I feel good when learning on my own spirit \\
\hline 3 & OL3 & I find difficulties when studying by e-learning \\
\hline 4 & OL4 & $\begin{array}{l}\text { I enjoy using e-learning as it bring more } \\
\text { Learning materials }\end{array}$ \\
\hline 5 & OL5 & I am willing to study using e-learning \\
\hline 6 & OL6 & $\begin{array}{l}\text { I prefer learning through website to face-to-face } \\
\text { learning in classrooms }\end{array}$ \\
\hline 7 & OL7 & I feel bored when studying through e-learning \\
\hline 8 & OL8 & I want learning time in classrooms shortened \\
\hline 9 & NOL5 & I certainly deny to learn using e-learning \\
\hline \multicolumn{3}{|c|}{ Attitude towards study management } \\
\hline 1 & SM1 & $\begin{array}{l}\text { I can arrange my time better when studying } \\
\text { through e-learning }\end{array}$ \\
\hline
\end{tabular}

TABLE I, Cont.

\begin{tabular}{|c|c|c|}
\hline 3 & SM3 & $\begin{array}{l}\text { I am encouraged to prepare studying better when } \\
\text { using e-learning }\end{array}$ \\
\hline 4 & SM4 & $\begin{array}{l}\text { I am encouraged to prepare study plans when } \\
\text { studying though e-learning }\end{array}$ \\
\hline 5 & SM5 & $\begin{array}{l}\text { I am more determined to be responsible to } \\
\text { assignments studying through e-learning }\end{array}$ \\
\hline 6 & NSM3 & $\begin{array}{l}\text { I am lack of interest to prepare when studying } \\
\text { though e-learning }\end{array}$ \\
\hline \multicolumn{3}{|r|}{ Attitude towards technology } \\
\hline 1 & $\mathrm{~T} 1$ & $\begin{array}{l}\text { I believe that websites are useful for teaching- } \\
\text { learning activities }\end{array}$ \\
\hline 2 & $\mathrm{~T} 2$ & I am accustomed to use websites \\
\hline 3 & T3 & I believe that websites are easy to use \\
\hline 4 & $\mathrm{~T} 4$ & $\begin{array}{l}\text { I think we have to use technology and teaching- } \\
\text { learning activities }\end{array}$ \\
\hline 5 & NT3 & I feel that websites are difficult to use \\
\hline \multicolumn{3}{|r|}{ Attitude towards online interaction } \\
\hline 1 & OI1 & I feel isolated when studying through e-learning \\
\hline 2 & OI2 & $\begin{array}{l}\text { I feel happy when using websites to exchange } \\
\text { information with other people }\end{array}$ \\
\hline 3 & $\mathrm{OI} 3$ & $\begin{array}{l}\text { I want to interact with teachers and instructors } \\
\text { through internet }\end{array}$ \\
\hline 4 & $\mathrm{OI} 4$ & $\begin{array}{l}\text { I want to interact with other students from other } \\
\text { classes }\end{array}$ \\
\hline 5 & OI5 & $\begin{array}{l}\text { I feel easy to communicate with other people } \\
\text { through internet }\end{array}$ \\
\hline 6 & OI6 & $\begin{array}{l}\text { I want to be able to contact teachers and } \\
\text { instructors easily through internet }\end{array}$ \\
\hline 7 & NOI3 & $\begin{array}{l}\text { I want to interact with teachers and instructors } \\
\text { through internet }\end{array}$ \\
\hline \multicolumn{3}{|r|}{ Attitude towards class learning } \\
\hline 1 & CL1 & $\begin{array}{l}\text { I find togetherness when meeting with my peers } \\
\text { in classrooms }\end{array}$ \\
\hline 2 & CL2 & $\begin{array}{l}\text { I like the rapid responses from teachers and } \\
\text { instructors when meeting with them directly }\end{array}$ \\
\hline 3 & CL3 & $\begin{array}{l}\text { I believe that face-to-face teaching-learning } \\
\text { activities will bring better achievement }\end{array}$ \\
\hline 4 & CL4 & $\begin{array}{l}\text { I will learn better when someone guides me on } \\
\text { private basis }\end{array}$ \\
\hline 5 & CL5 & $\begin{array}{l}\text { I will learn better when teachers and instructors } \\
\text { guide me }\end{array}$ \\
\hline 6 & NCL1 & $\begin{array}{l}\text { I find no togetherness when meeting with other } \\
\text { students in classrooms }\end{array}$ \\
\hline \multicolumn{3}{|r|}{ Readiness for blended learning } \\
\hline 1 & BL1 & $\begin{array}{l}\text { I want to follow teaching-learning sessions using } \\
\text { e-learning and face-to-face teaching-learning } \\
\text { activities in classrooms }\end{array}$ \\
\hline 2 & BL2 & $\begin{array}{l}\text { I want to attend teaching-learning sessions using } \\
\text { e-learning and face-to-face teaching-learning } \\
\text { activities in classrooms }\end{array}$ \\
\hline 3 & NBL1 & $\begin{array}{l}\text { I do not want to attend teaching-learning sessions } \\
\text { using e-learning and face-to-face teaching- } \\
\text { learning activities in classrooms }\end{array}$ \\
\hline
\end{tabular}

Each question is arranged in scales as described in the following table:

TABLE II. CRITERION SCORE FOR PRESENTATION RANGE

\begin{tabular}{|c|c|}
\hline Range & Result \\
\hline $0-20 \%$ & Strongly Disagree \\
\hline $21-40 \%$ & Disagree \\
\hline $41-60 \%$ & Neutral \\
\hline $61-80 \%$ & Agree \\
\hline $81-100 \%$ & Strongly Agree \\
\hline
\end{tabular}




\subsection{Respondents Profile}

The total number of respondents involved in the research was 103, comprising students of class $1(36 \%)$ and students of class $2(64 \%)$ that follow e-learning training programs. It exceeded the number of required samples, i.e.: 88 students. However, based on the results of face validity test, only 93 respondents considered to involve in the research.. Because 10 questionnaires did not pass the test face validity.

\subsection{The Results of Reliability, Validity, and Linearity Test}

Reliability The reliability test was adopted to show the extend of the consistency and reliability of results of measurement by the research instruments if the same measurement was repeated. The reliability test adopted with reference to the value of Cronbach's Alpha of each variable. A data is regarded reliable when the Cronbach's Alpha $\geq 0,6$. Indicators CL1 and CL4 were deleted so that all variables in the research were reliable in the second reliability test.

The validity was tested to identify the extend of the validity of the research instruments used in the process of data collection. The validity test in the research adopted product moment correlation proposed by Pearson, subject to 0.05 significance level in two-tail tests. The statements in the distributed questionnaire were regarded valid when the value of pearson correlation $\geq 0,202$ [10]. The final results of the validity test showed that the indicators of the research variable were valid.

A linearity test is one on tests to be adopted since it shows an assumption of relation in an equation required in a SEM test [11]. A relation is assumed to be linear when the $p$ value that represents the consistence of inter-variable relation, is less than 0.5 . The results of the linearity test showed that all intervariable relations were linear.

TABLE III. LINEARITY TEST RESULT

\begin{tabular}{|c|c|c|}
\hline Variable & $\begin{array}{c}\text { Linearity } \\
\text { Significance }\end{array}$ & Remarks \\
\hline LF -> BLA & 0,00 & Significantly Linier \\
\hline OL -> BLA & 0,00 & Significantly Linier \\
\hline SM -> BLA & 0,00 & Significantly Linier \\
\hline TE -> BLA & 0,00 & Significantly Linier \\
\hline OI -> BLA & 0,00 & Significantly Linier \\
\hline BLA -> BL & 0,00 & Significantly Linier \\
\hline CL -> BL & 0,00 & Significantly Linier \\
\hline
\end{tabular}

\subsection{Inferential Test Results}

An inferential analysis is applied to data passing validity, reliability and linearity tests by means of GeSCA online application.

Generalized structural componen analysis (GeSCA) is an analytical approach developed for substituting factors with linear combinations of indicators in SEM analysis. There are three phases in the GeSCA evaluation model. The first is evaluating the measurement. The second is evaluating the structural model. The last is evaluating the overall goodness of FIT model [12].

\subsubsection{Outer Model Analysis}

An outer model test is applied to measure the Convergent Validity, Composite Reliability and AVE, and Discriminant Validity.

The Convergent Validity Test is tested to identify the loading factor of each indicators forming latent variables. The convergent validity is assumed to be good when the loading factor in the latent variables is $>0.5$.In case the loading factor is $<0.5$, the indicator may be deleted in order to attain required level of significance.

The Composite Reliability shown by the value of Cronbach's Alpha represents the internal consistency reliability of research variables. The value of composite reliability recommended is to be $\geq 0.6$.

An Average Variance Extracted (AVE) is measured to exhibit the component score of latent variables. An AVE is assumed to be good when it is $>0.5$. In case the value of the Cronbach's Alpha is $\geq 0.6$ and the value of AVE value is $\geq 0.5$, the variable used in the research is reliable.

The following table shows the results of outer model tests after corrections twice to reach loading factor $<0.5$ for each indicator.

TABLE IV. OUTER MOdEl RESUlt

\begin{tabular}{|c|c|c|c|}
\hline \multirow{2}{*}{ Variable } & \multicolumn{3}{|c|}{ Loading } \\
\hline & Estimate & SE & $\mathbf{C R}$ \\
\hline $\mathbf{L F}$ & \multicolumn{3}{|c|}{ AVE $=0,626$ Alpha $=0,700$} \\
\hline LF2 & 0.821 & 0.038 & $21.64^{*}$ \\
\hline LF3 & 0.773 & 0.050 & $15.58^{*}$ \\
\hline LF4 & 0.778 & 0.067 & $11.54^{*}$ \\
\hline OL & \multicolumn{3}{|c|}{ AVE $=0,688$ Alpha $=0,772$} \\
\hline OL4 & 0.857 & 0.037 & $23.19 *$ \\
\hline OL5 & 0.860 & 0.031 & $27.68^{*}$ \\
\hline OL6 & 0.768 & 0.049 & $15.59 *$ \\
\hline $\mathbf{S M}$ & \multicolumn{3}{|c|}{ AVE $=0,601$ Alpha $=0,770$} \\
\hline SM1 & 0.606 & 0.109 & $5.55^{*}$ \\
\hline SM2 & 0.778 & 0.037 & $20.94 *$ \\
\hline SM3 & 0.829 & 0.035 & $23.43^{*}$ \\
\hline SM4 & 0.863 & 0.035 & $24.55^{*}$ \\
\hline TE & \multicolumn{3}{|c|}{ AVE $=0,587$ Alpha $=0,631$} \\
\hline TE2 & 0.804 & 0.063 & $12.83^{*}$ \\
\hline TE3 & 0.870 & 0.023 & $37.25^{*}$ \\
\hline TE4 & 0.597 & 0.155 & $3.84 *$ \\
\hline OI & \multicolumn{3}{|c|}{ AVE $=0,590$ Alpha $=0,649$} \\
\hline OI3 & 0.822 & 0.049 & $16.78^{*}$ \\
\hline OI4 & 0.665 & 0.080 & $8.27 *$ \\
\hline OI6 & 0.807 & 0.045 & 17.87* \\
\hline $\mathbf{C L}$ & \multicolumn{3}{|c|}{$\mathrm{AVE}=0.558$, Alpha $=0.600$} \\
\hline CL2 & 0.763 & 0.050 & $15.32 *$ \\
\hline CL3 & 0.749 & 0.070 & $10.65^{*}$ \\
\hline
\end{tabular}


TABEL IV, Cont.

\begin{tabular}{|c|c|c|c|}
\hline CL5 & 0.729 & 0.090 & $8.12^{*}$ \\
\hline \multicolumn{4}{|c|}{ AVE $=\mathbf{0 , 8 0 8}$ Alpha $=\mathbf{0 , 7 6 0}$} \\
\hline BL & 0.908 & 0.028 & $32.36^{*}$ \\
\hline BL1 & 0.890 & 0.028 & $32.33^{*}$ \\
\hline
\end{tabular}

\subsubsection{Discriminant Validity Analysis}

This method is adopted to test whether the adopted measurement instruments have weak correlation with variables that should not have relations. In case the value of the AVE square root of each variable is $\geq$ the one of correlation between the variable and other variables in the model, it is concluded that the discriminant validity is good.

The following table shows the results of discriminant validity test.

TABLE V. DISCRIMINAT VALIDITY

\begin{tabular}{|c|c|c|c|c|c|c|c|}
\hline Variable & $\mathbf{L F}$ & OL & SM & TE & OI & CL & BL \\
\hline AVE & 0,626 & 0,688 & 0,601 & 0,587 & 0,590 & 0,558 & 0,808 \\
\hline$\sqrt{A V E}$ & 0,791 & 0,829 & 0,775 & 0,766 & 0,768 & 0,746 & 0,898 \\
\hline $\mathbf{L F}$ & & 0.137 & 0,433 & 0,427 & $\begin{array}{c}- \\
0,017 \\
\end{array}$ & $\begin{array}{c}- \\
0,440 \\
\end{array}$ & 0,590 \\
\hline OL & 0,137 & & 0,463 & 0,278 & 0,327 & $\begin{array}{c}- \\
0,292\end{array}$ & 0,366 \\
\hline SM & 0.433 & 0,463 & & 0.487 & 0,311 & $\begin{array}{c}- \\
0,635\end{array}$ & 0,843 \\
\hline TE & 0.427 & 0.278 & 0.487 & & 0,152 & $\begin{array}{c}- \\
0,405\end{array}$ & 0,546 \\
\hline OI & $\begin{array}{c}- \\
0,017\end{array}$ & 0,327 & 0,311 & 0,152 & & $\begin{array}{c}- \\
0,146\end{array}$ & 0,254 \\
\hline CL & $\begin{array}{c}- \\
0,440\end{array}$ & $0, \overline{292}$ & $-0,635$ & $\begin{array}{c}- \\
0,405 \\
\end{array}$ & $\begin{array}{c}- \\
0,146\end{array}$ & & $\begin{array}{c}- \\
0,731\end{array}$ \\
\hline BL & 0,590 & 0,335 & 0,843 & 0,546 & 0,217 & $0, \overline{731}$ & \\
\hline Conclusion & Good & Good & $\begin{array}{l}\text { Good } \\
\text { Enough }\end{array}$ & Good & Good & Good & Good \\
\hline
\end{tabular}

The Discriminant validity of variables LF,OL,TE, OI, $\mathrm{CL}$, and BL is Good. It shows that the indicator of each variable does not correlate with other variables. On the other hands, the discriminant validity of SM variable is Good Enough. It shows that the indicator of other variables still correlates with the variable.

\subsubsection{Inner Model Analysis}

An Inner Model Analysis is a structure analysis to identify R2 and path coefficient. R2 describes the ability of an independent variable to support dependent variable. The closer the value of R2 to value 1 is, the better the variable to support the independent variables.

With reference to the value of $\mathrm{R} 2$, it shows that value of BLA variable is $\mathrm{R} 2=1.000$. It shows that the BLA variability is explainable by variability of LF, OL, SM, TE, and OI by $100 \%$. Meanwhile, the value of $\mathrm{BL}$ variable is $\mathrm{R} 2=0.821$. It shows that the $\mathrm{BL}$ variability is explainable by the variability of BLA and CL by $82.1 \%$.

In addition, an Overall Goodness of Fit Test was also conducted with the following results.
TABLE VI. GOODNESS OF FIT TEST RESULT

\begin{tabular}{|c|c|}
\hline \multicolumn{2}{|c|}{ Model Fit } \\
\hline FIT & 0,517 \\
\hline AFIT & 0,503 \\
\hline
\end{tabular}

The above Table VI explain that all variables can explain the model by 0.517 . The FIT value shows that variables $\mathrm{LF}$, OL, SM, TE, OI, BLA, CL, and BL can explain the model by $51.7 \%$, while the rest $48.3 \%$ can be explained by other variables not included in the model.

Next, a path coefficient test was adopted. Referring to the results of the calculation in this research, the results of the path coefficient test are as follows:

TABLE VII. PATH COEFFICIENT RESULT

\begin{tabular}{|l|c|c|c|}
\hline & Estimate & SE & CR \\
\hline LF -> BLA & 0.277 & 0.073 & $3.77^{*}$ \\
\hline OL -> BLA & -0.084 & 0.078 & 1.07 \\
\hline SM -> BLA & 0.800 & 0.076 & $10.49^{*}$ \\
\hline TE -> BLA & 0.131 & 0.087 & 1.5 \\
\hline OI -> BLA & 0.018 & 0.072 & 0.25 \\
\hline CL -> BL & -0.258 & 0.084 & $3.07^{*}$ \\
\hline BLA -> BL & 0.714 & 0.072 & $9.96^{*}$ \\
\hline
\end{tabular}

\section{The above table explains as follows:}

\section{LF $>$ BLA}

The variable of attitude towards learning flexibility and the variable of blended learning adaptability had significant relationship as the value of CR $(=3.77)$ was > the value of $T$ Table, and the value of regression coefficient was 0.277 . It showed that it had positive correlation. Conclusion: Variable of attitude towards learning flexibility positively and significantly affected the blended learning adaptability.

\section{OL $\geq B L A$}

Variabel of ttitude towards online learning and variable of blended learning adaptability did not correlate as their CR value $(=1.07)$ were $<$ the value of $T$ Table. Conclusion: Variable of attitude towards online learning did not affect the blended learning adaptability.

\section{3. $\mathrm{SM} \geq \mathrm{BLA}$}

Variable of attitude towards study management and variable of blended learning adaptability had significant relationship as their CR value $(=10.49)>$ the value of $T$ Table and the regression coefficient was 0.800 . It showed that it had positive correlation. Conclusion: Variable of attitude towards study management positively and significantly affected the blended learning adaptability.

\section{4. $\mathrm{TE} \geq \mathrm{BLA}$}

Variable of attitude towards technology and variable of blended learning adaptability did not correlate as their CR value $(=1.5)$ were < the value of T Table. Conclusion: Variable of attitude towards technology did not affect blended learning adaptability. 


\section{OI $\geq$ BLA}

Variable of attitude towards online interaction and variable of blended learning adaptability did not correlate as their CR value $(=0.25)$ was $<$ the value of $T$ Table. Conclusion: Variabel of attitude towards online interaction did not affect blended learning adaptability.

\section{6. $\mathrm{CL} \geq \mathrm{BL}$}

Variable of attitude towards classroom learning an variable of readiness for blended learning significantly correlated as their CR value $(=3.07)$ were $>$ the value of $T$ Table and the regression coefficient was 0.258 . It shows that it had positive correlation. Conclusion: Variable of attitude towards classroom negatively and significantly affected the readiness for blended learning.

7. $\mathrm{BLA} \geq \mathrm{BL}$

Variable of blended learning adaptability and variable of readiness for blended learning had significant correlation as their CR value $(=9.96)$ was $>$ the value of $T$ Table and the regression coefficient was 0.714 . It showed that it had positive correlation. Conclusion: Variale of blended learning adaptability positively and significantly affected readiness for blended learning.

Referring to the inner model analysis result, it was conclusive that the hypothesis in the research were as follows:

TABLE VIII. HYPOTHESES TESTING RESULT

\begin{tabular}{|c|c|c|c|}
\hline Hypotheses & Estimate & CR & Conclusion \\
\hline H1a & 0.270 & $3.77^{*}$ & Accepted \\
\hline H1b & -0.079 & 1.07 & Rejected \\
\hline H1c & 0.808 & $10.49^{*}$ & Accepted \\
\hline H1d & 0.136 & 1.5 & Rejected \\
\hline H1e & -0.013 & 0.25 & Rejected \\
\hline H2 & -0.257 & $3.07^{*}$ & Accepted \\
\hline H3 & 0.715 & $9.96^{*}$ & Accepted \\
\hline
\end{tabular}

The hypothesis testing result shows that the accepted hypotheses are hypothesis H1a, hypothesis H1c, hypothesis $\mathrm{H} 2$, and hypothesis H3. Meanwhile, there are three rejected hypotheses, namely hypothesis $\mathrm{H} 1 \mathrm{~b}$, hypothesis $\mathrm{H} 1 \mathrm{~d}$, and hypothesis H1e.

- H1a: Attitude towards learning flexibility provides a significant positive effect on Blended learning adaptability

- H1b: Attitude towards online learning provides a significant negative effect on Blended learning adaptability

- H1c: Attitude towards study management provide a significant positive effect on Blended learning adaptability

-H1d: Attitude towards technology provides no significant positive influence on Blended learning adaptability

- H1e: Attitude towards online interaction provides no significant negative effect on Blended learning adaptability
-H2: Blended learning adaptability provide a significant positive effect on Readiness for blended learning

- H3: Attitude towards classroom learning provide a significant positive effect on Readiness for blended learning

\subsubsection{Readiness Evaluation Results}

The readiness was evaluated by considering the total average value of each variable and interpreting the value by establishing evaluation criteria based on the e-LRS evaluation model advocated by Aydin and Tasci.

Aydin and Tasci have developed an e-learning readiness model consisting of four factors inherent in each concepts [15], i.e.: Technology, Innovation, People, and SelfDevelopment. In order to better assess the readiness, Aydin and Tasci have developed e-LRS assessment model (e-Leaning Readiness System) identified in Likert scales in indexes: 1, 2, 3 , 4, and 5. The mean is 3.41 and it will be identified as an expected degree of readiness in each factor. According to Aydin and Tasci, the various degrees of readiness are presented in the following Figure 2.

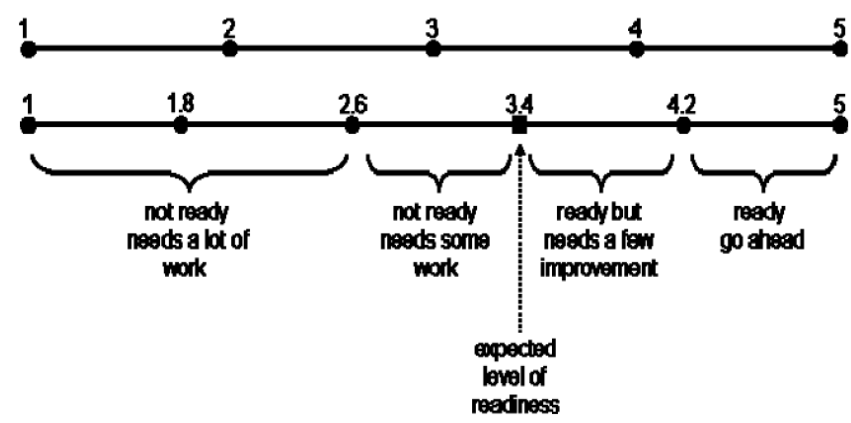

Fig. 2. e-LRS Model by Aydin and Tasci

Table IX shows the results of readiness evaluation to implement e-learning for the students of SMP Negeri 1 Jember.

TABLE IX. READINESS MEASUREMENT RESULT

\begin{tabular}{|c|c|c|}
\hline Variabel & Average & Readiness Result \\
\hline LF & 5.01 & Ready, but requiring minor improvement \\
\hline OL & 3.94 & Not ready and requiring major improvements \\
\hline SM & 4.49 & Ready, but requiring minor improvement \\
\hline TE & 4.75 & Ready, but requiring minor improvement \\
\hline OI & 4.56 & Ready, but requiring minor improvement \\
\hline BLA & 4.54 & Ready, but requiring minor improvement \\
\hline CL & 3.58 & Not ready and requiring major improvements \\
\hline BL & 4.96 & Ready, but requiring minor improvement \\
\hline
\end{tabular}

\section{CONCLUSION}

From this research on the analysis of the implementation of e-learning readiness in SMP Negeri 1 Jember based on Blended Learning Readiness Model can be obtained that students in SMP Negeri 1 Jember could be referred to be ready to implement e-learning, but still requires a bit of improvement. From several variables that affect the 
implementation of e-learning readiness, students state that they are ready the most of their attitude to the balance between academic, work, and time with family (Attitude towards learning flexibility), the attitude shown students to learning management (attitude towards study management), the student's ability to implement blended learning (blended learning adaptability), and attitudes towards learning in the classroom (attitude towards classroom learning), as well as their attitudes toward technology.

The main recommendations in this study include:

1. Students are able to set learning goals through elearning in order to have more attention toward the goals to be achieved and to plan things to be done within the time limit available so that the goals that have been determined can be achieved.

\section{REFERENCES}

[1] D. E. Hartley, "Selling E-Learning," Alexandria: American Society for Training and Development, 2001.

[2] I. M. Hefzallah, "The new Educational technologies and learning," Springfield: Charles C. Thomas, 2009.

[3] D. H. Lim, M. L. Morris, and V. W. Kupritz, Online VS Blended Learning : Difference In Industrial Outcomes and Learner Satisfaction. 2007.

[4] H. Siritongthaworn, S., Krairit, D., Dimmitt, N. J., \& Paul, "The study of e-learning technology implementation: A preliminary investigation of universities in Thailand," Educ. InformationTechnology, vol. 11, pp. 137-160, 2006.

[5] T. Volery and D. Lord, "Critical success factors in online education,” Int. J. Educ. Manag., vol. 14, pp. 216-223, 2000.

[6] S. Ozkan and R. Koseler, "Multi-dimensional students evaluation of e-learning systems in the higher education context: An empirical investigation," Comput. Educ., vol. 53, pp. 1285-1296, 2009.

[7] S. A. Borotis and A. Poulymenkou, E-Learning Readiness Components: Key Issues to Consider Before Adopting eLearning Interventions. 2004.

[8] P. Harris, J. Connolly, and L. Feeney, "Blended learning: Overview and recommendation for successful implementation," Ind. Commer. Train., vol. 41, pp. 155163, 2009.

[9] C. M. Tang and L. Y. Chaw, "Readiness for Blended Learning: Understanding Attitude of University Students," Int. J. Cyber Soc. Educ., vol. 6, pp. 79-100, 2013.

[10] Solimun, Multivariate Analysis Structural Equation Modelling (SEM) Lisrel dan Amos. Fakultas MIPA, Universitas Brawijaya, 2002.

[11] A. Subriadi, "INFORMATION TECHNOLOGY PRODUCTIVITY PARADOX: A RESOURCE-BASED VIEW AND INFORMATION TECHNOLOGY STRATEGIC ALIGNMENT PERSPECTIVE FOR MEAS URING INFORMATION TECHNOLOGY CONTRIBUTION ON PERFORMANCE," J. Theor. Appl. Inf. Technol., vol. 54, no. 3, pp. 541-552, 2013.

[12] K. Aprilian and I. Ghozali, Generalized Structured Component Analysis (GeSCA) - Component Based Structural Equation Model. Universitas Diponogoro Semarang, 2013.

[13] R. Papp, "Critical success factors for distance learning," in AMCIS, Americas Conference on Information Systems (AMCIS2000), 2000, pp. 1857-1861.
2. Teachers are able to make educated students to learn more

3. Teachers are able to use five international standard applications that can be used for educational purposes in order to communicate with students online using email, mailing lists, news groups, file transfer protocol (FTC) or world wide web (WWW).

[14] K. F. Soong, M. . B., Chan, H. C., Chua, B. C., \& Loh, "Critical success factors for online course resources," Comput. Educ., vol. 36, pp. 101-120, 2001.

[15] T. Govindasamy, "Successful implementation of elearning; pedagogical considerations," Internet High. Educ., vol. 2, no. 2-3, pp. 87-105.

[16] D. Y. Shee and Y. Wang, "Multi-criteria evaluation of the web-based elearning system: A methodology based on learner satisfaction and its applications," Comput. Educ., vol. 50, pp. 894-905, 2008.

[17] P. Mungania, "The seven e-learning barriers facing employees," in Research Final Report of The Masie Center of e-LEarning consortium, University of Louisville, USA. 2003.

[18] C. H. Aydin and D. Tasci, "Measuring Readiness for eLearning: Reflections from an Emerging Country," Educ. Technol. Soc., pp. 244-257, 2005. 